\title{
CLINICAL MANAGEMENT OF PREGNANCY TOXAEMIA IN A GOAT- A CASE REPORT
}

\author{
S. DHARA ${ }^{1 *}$ M. SHARMA ${ }^{1}$, A. K. SINGH ${ }^{2}$, \\ V. SHARMA ${ }^{1}$ AND S. THAKUR ${ }^{3}$
}

\begin{abstract}
${ }^{1}$ Department of Veterinary Gynaecology and Obstetrics, College of Veterinary and Animal Sciences, G.B.P.U.A. \& T, Pantnagar, U.S. Nagar-263 145, Uttarakhand, India

${ }^{2}$ Dept. of Veterinary Medicine, College of Veterinary and Animal Sciences, G.B.P.U.A. \& T, Pantnagar, U.S. Nagar-263 145, Uttarakhand, India

${ }^{3}$ Dept. of Veterinary Physiology and Biochemistry, College of Veterinary and Animal Sciences, G.B.P.U.A. \& T, Pantnagar, U.S. Nagar-263 145, Uttarakhand, India
\end{abstract}

\begin{abstract}
A three years old pregnant non-descriptive local doe was presented at TVCC, Pantnagar with a complaint of inappetence for last two days associated with circling movement and lateral deviation of neck. Weakness in both hind limbs and difficulty in standing was evident during physical examination. Clinical examination revealed congested mucus membrane and hypothermia $\left(99.8^{\circ} \mathrm{F}\right)$. X-ray and Ultrasonography revealed that the doe was carrying two viable foetuses that were about 145 days old. Urine analysis revealed presence of ketone bodies. Haemato-biochemical studies showed hypoglycaemia $(28 \mathrm{mg} / \mathrm{dL})$. The doe was immediately treated for pregnancy toxaemia with $500 \mathrm{~mL} 20 \%$ dextrose BID and $60 \mathrm{~mL} \mathrm{Mifex}{ }^{\circledR}$ OD intravenously for three days. In addition, glycerine@ $50 \mathrm{~mL}$ BID orally and $2 \mathrm{~mL}$ injection B-complex BID intramuscularly for three days were also given. After three days of successful treatment, parturition was induced with 250 $\mu \mathrm{g}$ cloprotenol sodium intramuscularly and $48 \mathrm{mg}$ valethamide bromide intramuscularly. The doe delivered two live foetuses within 24 hours of induction. This clinical case reports the clinical management of pregnancy toxaemia in a goat, which is a common problem in small holder farms in India.
\end{abstract}

Key words: Clinical management, Doe, Hypoglycaemia, Ketone bodies, Pregnancy toxaemia

Pregnancy toxaemia also known as 'twin lambs' disease, is a metabolic disorder of small ruminants caused by abnormal metabolism of carbohydrates (Brozos et al., 2011). It commonly occurs in does during late gestation as well as early lactation (Affan et al., 2018). The does carries twins or triplets are highly susceptible to such occurrence (Ermilio and Smith, 2011; Mohan et al., 2018). The main cause of pregnancy toxaemia in goat is a disturbance in carbohydrate metabolism due to the high demands for glucose by the multiple developing foetuses in the last trimester along with low level of nutrition (Jesse et al., 2016) produces negative energy balance (Amirul et $a l ., 2016)$. Due to this hypoglycaemic condition body produces glucose from other noncarbohydrate substances such as fat. It causes increased free fatty acid (FFA) and ketone bodies in plasma as well as in urine due to lipolysis (Chaiyabutr et al., 1980; Abba et al., 2015). In severe condition, morbidity and

${ }^{*}$ Corresponding Author 
mortality reach up to $20 \%$ and $80 \%$, respectively (Ismail et al., 2008). Early clinical signs of pregnancy toxaemia in doe include reduced appetite, listlessness, aimless walking, muscle twitching, fine muscle tremor, and grinding of teeth. In advance cases the animal goes to lateral recumbency, coma or even up to death of the animal. The main objective of treatment of pregnancy toxaemia is to increase the formation of glucose for utilization at tissue level and decrease the level of ketone bodies (Jesse et al., 2016).

A three years old pluriparous non descriptive local doe (4.8 months pregnant) (Fig. 1), weighing $35 \mathrm{~kg}$ was presented to Teaching Veterinary Clinical Complex, Pantnagar, Uttarakhand with the history of circling movement, deviation of head, weakness in hind limbs and loss of appetite for last two days. Clinical examination revealed hypothermia $\left(99.8^{\circ} \mathrm{F}\right)$, congested mucous membrane and tachycardia. Physical examination revealed animal was dull, depressed and slightly dehydrated. Both the X-ray (Fig. 2) as well as USG (Fig. 3) reports confirmed the presence of two mature viable foetuses (approx. 145 days). Urine sample was positive for ketone bodies. Low blood glucose level $(28 \mathrm{mg} / \mathrm{dL})$ was detected using GOD-POD kit (Erba Glucose kit).

Based on history, clinical examination and laboratory examination the doe (Fig. 1) was diagnosed with pregnancy toxaemia.

Treatment was started with $500 \mathrm{~mL}$ DNS (20\%) BID intravenously and $100 \mathrm{~mL}$ NS BID intravenously, for three days to compensate glucose level and dehydration. Glycerol $(50 \mathrm{~mL}$, BID) orally supplemented for three days as glucose precursor. In addition, $60 \mathrm{~mL}$ Mifex $^{\circledR}$ OD intravenously for three days as calcium supplement and $2 \mathrm{~mL}$ vitamin B-complex BID intramuscularly for three days as supportive therapy were given. After three days of successful treatment (Fig. 4), medicinal induction of parturition was recommended. Induction was performed by administering $250 \mu$ g cloprostenol sodium intramuscularly and $48 \mathrm{mg}$ valethamide bromide intramuscularly. The doe delivered two live foetuses within 24 hours of induction.

Pregnancy toxaemia is a common metabolic disorder of small ruminants caused by abnormal metabolism of carbohydrate around last trimester as well as early lactation stages (Brozos et al., 2011). Specially at last trimester if the doe carries multiple foetuses the chances of pregnancy toxaemia become more due to increased demand of energy for growing foetuses (Bulgin, 2005). Anorexia, depression and separation from the herd are the first clinical signs of pregnancy toxaemia in a pregnant doe. As the disease progresses, animal will start showing neurological signs like depression, tremors, stargazing, ataxia, circling, teeth grinding and blindness due to encephalopathy that result from hypoglycaemia (Jesse et al., 2016).

In present case the animal showed symptoms of circling movement, recumbency, inappetance, hypothermia and trachycardia. X-ray as well as USG revealed presence of two mature viable foetuses. Urine and blood examination confirmed ketosis and hypoglycaemia. Based on above mention findings the present case was confirmed as pregnancy toxaemia. To combat the hypoglycaemic condition we treated the animal primarily with $20 \%$ dextrose as well as oral supplementation of glycerol as a source of glucose. Calcium was given to prevent the muscular atrophy. Other supportive drug like vitamin B complex was given to improve general health and combat the neurological complication of the animal. Within three days of treatment, the animal recovered completely. After recovery from pregnancy toxaemia, medicinal induction of parturition was performed with cloprotenol sodium and valethamide bromide. The doe delivered two live foetuses within 24 hours of induction. 
Indian Journal of Animal Health, June, 2020

\section{A clinical case report on pregnancy toxaemia in a goat}

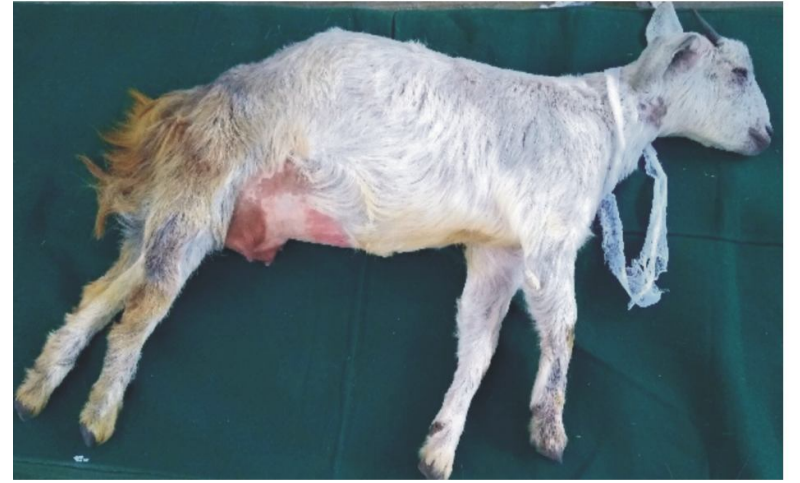

Fig. 1. Doe before treatment

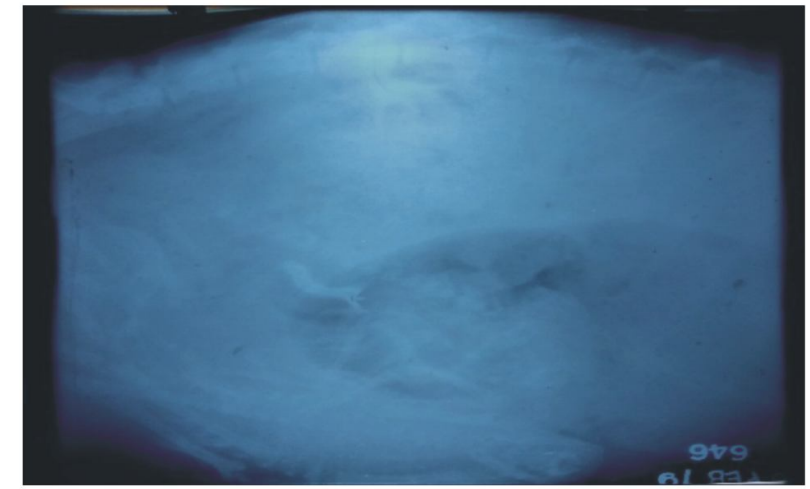

Fig. 2. Radiograph showing skeletons of the foetuses

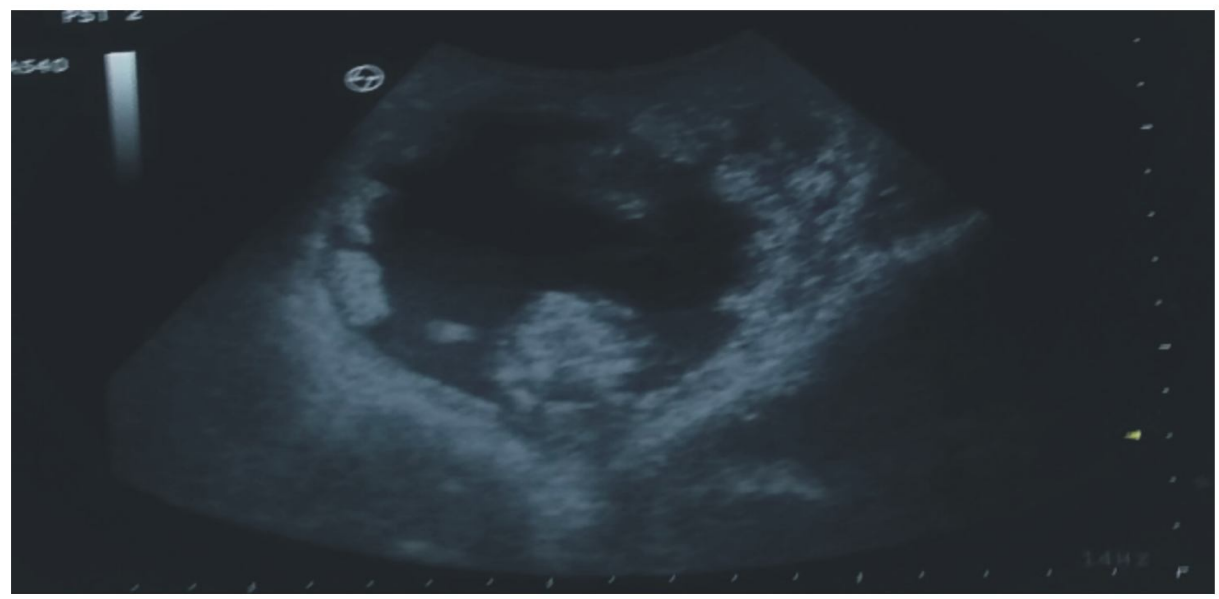

Fig. 3. USG showing live foetuses

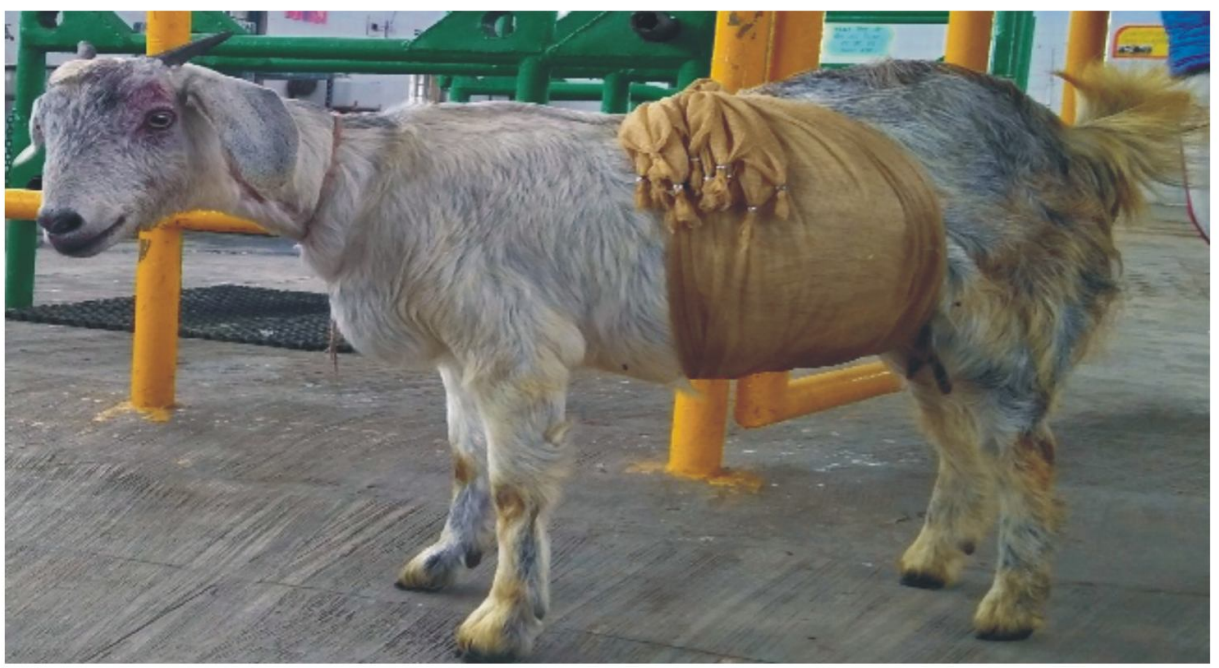

Fig. 4. Doe after treatment 
Glucose acts as a major source for energy for the developing foetus. In the last trimester due to rapidly growing foetuses, there is demand for excessive energy and adequate nutrition. In

\section{REFERENCES}

Abba Y, Abdullah FFJ, Chung ELT, Sadiq MA, Mohammed A et al., 2015. Biochemical and pathological findings of pregnancy toxemia in Saanen doe: A case report. J Adv Vet Anim Res, 2(2): 236-239

Affan AA, Amirul FMA, Ghani AAA, Annas S, ZamriSaad M et al., 2018. Serum biochemical, hormonal and fatty acid profiles during the late gestation of pregnancy ketosis in Boer cross goat. JITV, 23(4): 180-188, doi: 10.14334/ jitv.v23i4.1922

Amirul FMA, Mokrish A, Lai KS, Zamri-Saad M, Zuki $\mathrm{AB}$ et al., 2016. Clinical, biochemical and histological changes during development of pregnancy ketosis in goats. J Vet Malaysia, 28 (1): $1-6$

Brozos C, Mavrogianni VS and Fthenakis GC, 2011. Treatment and control of peri-parturient metabolic diseases; pregnancy toxemia, hypocalemia, hypomagnesemia. Vet Clin North Am Food Anim Pract, 27: 105-113

Chaiyabutr N, Faulkner A and Peaker M, 1980. Effects of starvation on cardiovascular function this present case recovery was possible due to early investigation, prompt diagnosis and immediate administration of energy sources and supplementary medicines to the affected animal.

(including the mammary circulation) and water balance in pregnant goats. Q J Exp Physiol CMS, 65(3): 207-216

Ermilio EM and Smith MC, 2011. Treatment of emergency conditions in sheep and goats. Vet Clin North Am Food Anim Pract, 27: 33-45

Ismail BZA, AI-Majali AM, Amireh F and AlRawashdeh O, 2008. Metabolic profiles in goat in late pregnancy with and without subclinical pregnancy toxaemia. Vet Clin Pathol, 37(4): 434-437

Jesse FFA, Chung ELT, Zakaria WNW, Abba Y, Sadiq MA et al., 2016. Clinical case of pregnancy toxaemia in a goat - A case report on veterinary medicine approach. Int J Live Res, 6(6): 76-81

Mohan SK, Aswathy C, Shonima P, Jacob S and Vishnu Prya V, 2018. Metabolic profiling of Malabari does with subclinical pregnancy toxaemia. Int J Res Pharma Sci, 9(3): 10271032

Bulgin MS, 2005. Pregnancy toxemia - An in depth review. Wool \& Wattles, 33: 9-10 